Research Article

Check for updates

OPEN ACCESS

Received: Jan 11, 2019

Accepted: May 9, 2019

"Correspondence:

Byoung Gwon Kim

Department of Occupational and

Environmental Medicine, College of Medicine,

Dong-A University, 32 Daesingongwon-ro,

Seo-gu, Busan 49201, Korea.

E-mail: medikim@dau.ac.kr

Copyright (c) 2019 Korean Society of

Occupational \& Environmental Medicine

This is an Open Access article distributed under the terms of the Creative Commons Attribution Non-Commercial License (https:// creativecommons.org/licenses/by-nc/4.0/) which permits unrestricted non-commercial use, distribution, and reproduction in any medium, provided the original work is properly cited.

ORCID IDS

Jeong Woo Kim (D)

https://orcid.org/0000-0002-2580-5951

Byoung Gwon Kim (iD)

https://orcid.org/0000-0002-1762-6320

Jeong Woo Park (iD)

https://orcid.org/0000-0002-2444-789X Jong Woo Yi (DD

https://orcid.org/0000-0002-2026-1174 Jung $\|$ Kim (iD)

https://orcid.org/0000-0002-9774-9581

Young Seoub Hong (iD)

https://orcid.org/0000-0002-9037-3761

\section{A study of relationship between blood mercury concentration and hypertension in residents living in old mine fields and related factors}

\author{
Jeong Woo Kim (i) ', Byoung Gwon Kim (ib)", Jeong Woo Park (i) ', Jong Woo Yi (i) ', \\ Jung II Kim (D) ${ }^{1}$, and Young Seoub Hong (D) ${ }^{2}$ \\ 'Department of Occupational and Environmental Medicine, College of Medicine, Dong-A University, Busan, \\ Korea \\ ${ }^{2}$ Heavy Metal Exposure Environmental Health Center, Dong-A University, Busan, Korea
}

Background: In Korea, around the abandoned metal mines, heavy metals are being accumulating in the cultivated areas. Among exposed heavy metals, mercury is known to harm for cardiovascular system known to affect blood pressure. So, we studied the relationship between blood mercury level and hypertension in residents around abandoned metal mines. Methods: From 2008 to 2011, we surveyed 7,055 residents in provinces affected by abandoned metal mines and collected data from 6 Hospitals. We conducted a personal questionnaire interview survey with residents on the basis of household questionnaires, sex, age, household income, smoking, and drinking items. Multiple logistic regression analysis was performed to investigate the association between blood mercury level and hypertension.

Results: We compared residents with low and high groups based on blood mercury level 5.8 $\mu \mathrm{g} / \mathrm{L}$, and higher group was significantly higher risk of hypertension than lower group (odds ratio [OR]: 1.277; 95\% confidence interval [CI]: 1.135-1.436), also in adjusted model, higher group was significantly higher risk of hypertension than lower group (OR: 1.276; 95\% CI: 1.117-1.457). Conclusions: This study showed a significant correlation between mercury and hypertension in residents around abandoned metal mines. Therefore, we should continuously monitor people who are higher than the standard value and the hypertensive patients.

Keywords: Blood mercury; Hypertension; Abandoned metal mines

\section{BACKGROUND}

Mercury exists in 3 forms: metal mercury, organic mercury, and inorganic mercury. Most forms of mercury present in the environment are metal mercury and inorganic mercury. Mercury in the atmosphere is not soluble in water. Even in rain, it only melts in a small amount and remains in the atmosphere, but it is finally oxidized to divalent mercury by reaction with atmospheric oxidizing agents such as oxygen, ozone and chlorine. Divalent mercury is water-soluble, stabilizing in water, and from the atmosphere into the soil due to precipitation. Elemental and inorganic mercury is deposited in watersheds or in direct waters. This mercury precipitates in sediments, some of which react with sulfate to form 
Abbreviations

OR: odds ratio; $\mathrm{Cl}$ : confidence interval; PSM propensity score matching; SD: standard deviation.

Funding

This study was supported by grants from the Environmental Health Center funded by the Ministry of Environment, Republic of Korea. This study was supported by research funds from Dong-A University.

Competing interests

The authors declare that they have no competing interests. The paper's contents are solely the responsibility of the author and do not necessarily represent the official vies of the Environmental Health Center, Dong-A University.

Availability of data and materials Not applicable.

\section{Authors contributions}

Conceptualization: Kim JW. Data curation: Hong YS, Kim JI, Park JW, Yi JW. Formal analysis: Hong YS, Kim JI, Park JW, Yi JW. Investigation: Hong YS, Kim JI, Park JW, Yi JW. Supervision: Kim BG. Writing - review \& editing: Kim JW insoluble mercury sulphide precipitates, whereas a few are methylated in vivo by bacteria. This methylmercury is readily bioavailable and the food chain is bio-concentrated, accumulated by aquatic organisms and exposed to human ingestion [1]. This exposed mercury is well known for its toxic effect on the central nervous system, and it can also harm for cardiovascular system known to affect blood pressure, parasympathetic and sympathetic effects [2], affecting the autonomic nervous system and causing harmful effects on heart rate $[3,4]$.

In Korea, old metal mines have not been properly treated since the development, polluting the surrounding soil and rivers, and heavy metals are being concentrated in the cultivated areas. In addition, since the heavy metal components contained in the waste mine and mine tailings generated during the ore mining process are accumulated in the surrounding soil for a long time, the pollution is caused not only in surrounding farmland but also in general living area [5]. Therefore, it is presumed that the residues of the residents around the mine area were exposed to heavy metals due to soil crops and drinking water.

In Korea, however, there is no clear standard for mercury concentration in the blood, and it follows the standards set by the US and Germany. Due to the lack of studies on the standard in Korea, we have studied the mercury concentration and the prevalence of hypertension in the residents around abandoned metal mines using US standard values.

\section{METHODS}

\section{Subjects and data collection}

From 2008 to 2011, we surveyed 7,055 residents in Gyeonggi, Gangwon, Gyeongnam, Gyeongbuk, Jeonla and Chungcheong provinces affected by abandoned metal mines and collected data from 6 hospitals. To investigate the demographic characteristics of the subjects, a questionnaire designed by the Korean Society of Epidemiology was used as a basis and modified to meet the purpose of the research. We conducted a personal questionnaire interview survey with residents on the basis of household questionnaires, sex, age, household income, smoking, and drinking items, and we used standardized questionnaires and questionnaires were prepared with the help of researchers.

\section{Classification of subjects}

We set standard value of mercury concentration in blood to $5.8 \mu \mathrm{g} / \mathrm{L}$ [6] and $15 \mu \mathrm{g} / \mathrm{L}$ [7] in order to divide high and low mercury concentrations among residents around abandoned metal mines. And we divided the residents into two groups less than $5.8 \mu \mathrm{g} / \mathrm{L}$ and equal or more than $5.8 \mu \mathrm{g} / \mathrm{L}$ (also $15 \mu \mathrm{g} / \mathrm{L}$ ). The $\chi^{2}$ test and t-test was used to analyze the difference of disturbance variables in these groups.

\section{Matching method}

In the present study, the difference between the disturbance variables of the two groups was minimized by using propensity score matching (PSM). PSM is a technique used to control dissimilarly distributed variables other than processing variables when comparing experimental and control groups.

\section{Measure blood pressure}

The checkup teams at each hospital took blood pressure and pulse measurements using a mercury sphygmomanometer. The criteria for hypertension were systolic blood pressure 
$\geq 140 \mathrm{mmHg}$ or diastolic blood pressure $\geq 90 \mathrm{mmHg}$ [8], or whether they were diagnosed through a medical history, and current hypertension and we include people who are taking hypertension medication and whose blood pressure is normal.

\section{Process the blood sampling}

Each hospital's screening team conducted blood sampling for the residents at the local community center. Blood samples were collected in heparin and treated tubes, mixed well with ethylenediaminetetraacetic acid to prevent clotting, and stored in refrigerator. All the samples were refrigerated and transferred to the analysis room after the medical examination.

\section{Analysis of blood mercury concentration}

Serum mercury was determined by gold-amalgam method using Direct Mercury analyzer (DMA 80; Milestone, Sorisole, Italy). The $100 \mu \mathrm{L}$ of well-stirred blood was placed in the sample container of the analyzer and immediately analyzed.

\section{Statistical analysis}

A geometric mean and a $95 \%$ confidence interval corrected for demographic characteristics and lifestyle were presented. All tests were conducted at a significance level of $5 \%$.

\section{Ethics statement}

This study used the data of the Research for Health Effects of the residents around the abandoned metal mines, 2008-2011, National Institute of Environmental Research. All study participants of the research agreed to participate the survey and signed a consent. This research was approved by the Dong-A University Institutional Review Board (No. 13-010).

\section{RESULTS}

\section{General characteristics of all subjects}

As a result of analyzing the total data of the residents, the mean blood mercury concentration was $5.22 \mu \mathrm{g} / \mathrm{L}$ (standard deviation: 4.53), and the results are shown in Table 1 .

Table 1. General characteristics of study subjects

\begin{tabular}{|c|c|c|c|c|c|c|c|c|}
\hline \multirow[t]{2}{*}{ Characteristics } & \multicolumn{4}{|c|}{ All subjects } & \multicolumn{4}{|c|}{ PSM subjects } \\
\hline & $\begin{array}{c}\mathrm{Hg}<5.8 \mu \mathrm{g} / \mathrm{L} \\
(\mathrm{n}=4,438)\end{array}$ & $\begin{array}{c}\mathrm{Hg} \geq 5.8 \mu \mathrm{g} / \mathrm{L} \\
(\mathrm{n}=1,737)\end{array}$ & $\chi^{2}$ or t-value & $p$-value & $\begin{array}{c}\mathrm{Hg}<5.8 \mu \mathrm{g} / \mathrm{L} \\
(\mathrm{n}=3,275)\end{array}$ & $\begin{array}{c}\mathrm{Hg} \geq 5.8 \mu \mathrm{g} / \mathrm{L} \\
(\mathrm{n}=1,833)\end{array}$ & $\chi^{2}$ or t-value & $p$-value \\
\hline Sex & & & 156.599 & 0.000 & & & 0.303 & 0.582 \\
\hline Male & $1,560(35.2)$ & $912(52.5)$ & & & 1,165 (26.3) & $595(34.3)$ & & \\
\hline Female & $2,878(64.8)$ & $825(47.5)$ & & & $1,665(37.5)$ & $820(47.2)$ & & \\
\hline Age (years) & $66.1 \pm 12.23$ & $63.68 \pm 11.33$ & 7.151 & 0.000 & $65.24 \pm 12.21$ & $65.35 \pm 10.90$ & 0.300 & 0.764 \\
\hline Smoking & & & 26.980 & 0.000 & & & 1.144 & 0.564 \\
\hline Current & $576(13.0)$ & 258 (14.9) & & & $409(9.2)$ & $212(12.2)$ & & \\
\hline Ex & $676(15.2)$ & 345 (19.9) & & & 431 (9.7) & $230(13.2)$ & & \\
\hline Non & 3,186 (71.8) & $1,134(65.3)$ & & & $1,990(44.8)$ & $973(56.0)$ & & \\
\hline Alcohol drink & & & 99.763 & 0.000 & & & 0.229 & 0.632 \\
\hline 1 & $1,731(39.1)$ & $923(53.1)$ & & & 1,298 (29.2) & $638(36.7)$ & & \\
\hline 0 & 2,701 (60.9) & $814(46.9)$ & & & $1,532(34.5)$ & 777 (44.7) & & \\
\hline Income & & & 38.340 & 0.000 & & & 0.971 & 0.808 \\
\hline 1 & $2,685(60.5)$ & $921(53.0)$ & & & 1,732 (39.0) & 847 (48.8) & & \\
\hline 2 & 809 (18.2) & $350(20.1)$ & & & $502(11.3)$ & $255(14.7)$ & & \\
\hline 3 & $593(13.4)$ & $260(15.0)$ & & & $381(8.6)$ & $196(11.3)$ & & \\
\hline 4 & $351(7.9)$ & 206 (11.9) & & & $215(4.8)$ & 117 (6.7) & & \\
\hline
\end{tabular}

Values are presented as number (\%). Alcohol drink: 1 - person who had lifetime drinking experience, 0 - never drink; Income: quartile subgroup for gross house income. PSM: propensity score matching. 
First, there was a statistically significant difference $(p<0.05)$ in sex, age, smoking, drinking and income for original data. In the age, the mean age was 66.10 in the group less than 5.8 $\mu \mathrm{g} / \mathrm{L}$, but the mean age was 63.68 in the group with $5.8 \mu \mathrm{g} / \mathrm{L}$ or more. After PSM match, there was no statistically significant difference in sex, smoking, and house income $(p>0.05)$.

\section{Association between general characteristic and mercury concentration}

Table 2 summarizes the differences in blood mercury concentrations according to general characteristics. First, the mean difference in mercury concentration between male and female was statistically significant $(p<0.05)$ and the male had higher blood mercury levels. The difference in mercury concentration by age was statistically significant $(p<0.001)$, and the mercury concentration was found to be higher at the age that below than 65 . In the case of drinking, the mean difference of mercury concentration was statistically significant $(p<0.001)$, indicating a high mercury concentration level in the lifetime drinkers. The mean difference in mercury concentration was statistically significant $(p<0.001)$, and the current smoker and quit smoker had a high mercury concentration level than never smoked people. In last, the mean difference in mercury concentration was statistically significant $(p<0.001)$ and the mercury concentration was the highest at income level 4 (highest level in income).

\section{Association of blood mercury concentration and hypertension}

Table 3 summarizes the $\chi^{2}$ test to determine whether there is a relationship between hypertension and blood mercury levels. When reference level was $5.8 \mu \mathrm{g} / \mathrm{L}$ in the original data, the occurrence of hypertension of lower group was $53.9 \%$ and higher group was $57.1 \%$, so the prevalence of hypertension was higher in the groups above $5.8 \mu \mathrm{g} / \mathrm{L}$ and there was a statistically significant difference $(p<0.05)$. In the PSM data using baseline characteristics, lower group $(<5.8 \mu \mathrm{g} / \mathrm{L})$ was $52.5 \%$, and higher group $(\geq 5.8 \mu \mathrm{g} / \mathrm{L})$ was $58.2 \%$. The prevalence of hypertension was higher in the groups above $5.8 \mu \mathrm{g} / \mathrm{L}$ and there was statistically significant $(p<0.05)$.

And when reference level was $15 \mu \mathrm{g} / \mathrm{L}$, in the original data, the occurrence of hypertension of lower group was $54.7 \%$ and higher group was $60.3 \%$, so the prevalence of hypertension was

Table 2. Differences in blood mercury concentrations according to general characteristics

\begin{tabular}{|c|c|c|c|}
\hline \multirow[t]{2}{*}{ Characteristics } & \multicolumn{3}{|c|}{ All subjects } \\
\hline & Mean \pm SD & t-value & $p$-value \\
\hline Sex & & 11.899 & 0.000 \\
\hline Male & $5.99 \pm 4.96$ & & \\
\hline Female & $4.56 \pm 4.38$ & & \\
\hline Age (years) & & 8.642 & 0.000 \\
\hline$<65$ & $5.74 \pm 4.67$ & & \\
\hline$\geq 65$ & $4.70 \pm 4.63$ & & \\
\hline Smoking & & 11.261 & 0.000 \\
\hline Current & $5.39 \pm 4.28$ & & \\
\hline Ex & $5.67 \pm 4.62$ & & \\
\hline Non & $4.95 \pm 4.75$ & & \\
\hline Alcohol drink & & 9.854 & 0.000 \\
\hline 1 & $5.80 \pm 4.98$ & & \\
\hline 0 & $4.62 \pm 4.36$ & & \\
\hline Income & & 25.510 & 0.000 \\
\hline 1 & $4.73 \pm 4.10$ & & \\
\hline 2 & $5.41 \pm 5.63$ & & \\
\hline 3 & $5.71 \pm 5.26$ & & \\
\hline 4 & $6.25 \pm 4.73$ & & \\
\hline
\end{tabular}

Alcohol drink: 1 - person who had lifetime drinking experience, 0 - never drink; Income: quartile subgroup for gross house income.

SD: standard deviation 
Table 3. Differences in blood mercury concentration according to hypertension existence

\begin{tabular}{|c|c|c|c|c|c|c|c|c|}
\hline \multirow{3}{*}{$\begin{array}{l}\text { Hg concentration } \\
(\mu \mathrm{g} / \mathrm{L})\end{array}$} & \multicolumn{4}{|c|}{ All subjects } & \multicolumn{4}{|c|}{ PSM subjects } \\
\hline & \multicolumn{2}{|c|}{ Hypertension } & \multirow[t]{2}{*}{$\chi^{2}$} & \multirow[t]{2}{*}{$p$-value } & \multicolumn{2}{|c|}{ Hypertension } & \multirow[t]{2}{*}{$\chi^{2}$} & \multirow[t]{2}{*}{$p$-value } \\
\hline & Yes & No & & & Yes & No & & \\
\hline$>5.8$ & 2,394 (53.9) & $2,044(46.1)$ & 4.873 & 0.027 & $1,486(52.5)$ & $1,344(47.5)$ & 12.155 & 0.001 \\
\hline$\leq 5.8$ & 991 (57.1) & $746(42.9)$ & & & 823 (58.2) & $592(41.8)$ & & \\
\hline$>15$ & $3,263(53.9)$ & $2,703(45.3)$ & 2.552 & 0.110 & $214(51.2)$ & $204(48.8)$ & 4.639 & 0.031 \\
\hline$\leq 15$ & $126(60.3)$ & $83(39.7)$ & & & $126(60.3)$ & $83(39.7)$ & & \\
\hline
\end{tabular}

Values are presented as number (\%).

PSM: propensity score matching.

higher in the groups above $15 \mu \mathrm{g} / \mathrm{L}$ but there was no statistically significant difference $(p>0.05)$. In the PSM data using baseline characteristics, lower group $(<15 \mu \mathrm{g} / \mathrm{L})$ was $51.2 \%$, and higher group $(\geq 15 \mu \mathrm{g} / \mathrm{L}$ ) was $60.3 \%$. The prevalence of hypertension was higher in the groups above 15 $\mu \mathrm{g} / \mathrm{L}$ and there was statistically significant $(p<0.05)$.

\section{Analysis of factors related to hypertension}

Logistic regression analysis was used to analyze factors affecting hypertension, and sex, age, smoking, drink, income and mercury concentration were set as influential variables. The logistic regression results are summarized in Tables $\mathbf{4}$ and $\mathbf{5}$. When reference level was $5.8 \mu \mathrm{g} / \mathrm{L}$ in the original data, mercury concentration, age, income had statistically significant effects on hypertension $(p<0.05)$, and the odds ratio (OR) of mercury in blood was 1.277 , which means the high mercury concentration group showed a $27.7 \%$ higher risk of developing hypertension than the lower group. In the PSM data, mercury concentration, age, and income had statistically significant effects on hypertension $(p<0.05)$, and the OR of mercury in blood was 1.276, which means the high mercury concentration group showed a $27.6 \%$ higher risk of developing hypertension than the lower group.

And when reference level was $15 \mu \mathrm{g} / \mathrm{L}$ in the original data, mercury concentration, age, income had statistically significant effects on hypertension $(p<0.05)$, and the OR of mercury in blood was 1.426, which means the high mercury concentration group showed a $42.6 \%$ higher risk of developing hypertension than the lower group. In the PSM data, mercury concentration, age had statistically significant effects on hypertension $(p<0.05)$, and the OR of mercury in blood was 1.450 , which means the high mercury concentration group showed a $45.0 \%$ higher risk of developing hypertension than the lower group.

Table 4. Logistic regression analysis for the occurrence of hypertension and related factors (Hg concentration $5.8 \mu \mathrm{g} / \mathrm{L}$ )

\begin{tabular}{|c|c|c|c|c|}
\hline \multirow[t]{2}{*}{ Related factors } & \multicolumn{2}{|l|}{ All subjects } & \multicolumn{2}{|l|}{ PSM subjects } \\
\hline & OR $(95 \% \mathrm{Cl})$ & $p$-value & OR $(95 \% \mathrm{Cl})$ & $p$-value \\
\hline Hg concentration (ref $\geq 5.8$ ) & $1.277(1.135-1.436)$ & $<0.001$ & $1.276(1.117-1.457)$ & 0.000 \\
\hline Sex $(r e f=$ male $)$ & $0.978(0.857-1.115)$ & 0.737 & $1.024(0.875-1.198)$ & 0.766 \\
\hline Age & 1.038 (1.033-1.043) & $<0.001$ & 1.040 (1.034-1.047) & $<0.001$ \\
\hline Smoking (ref = current) & & 0.575 & & 0.665 \\
\hline Ex & $0.984(0.814-1.190)$ & 0.869 & $0.901(0.716-1.134)$ & 0.376 \\
\hline Non & $1.062(0.895-1.261)$ & 0.489 & $0.958(0.777-1.181)$ & 0.686 \\
\hline Alcohol drink $(r e f=0)$ & 0.987 (0.879-1.108) & 0.827 & $0.934(0.819-1.065)$ & 0.308 \\
\hline Income $($ ref $=1)$ & & 0.003 & & 0.028 \\
\hline 2 & 1.000 (0.868-1.151) & 0.996 & 1.009 (0.849-1.199) & 0.922 \\
\hline 3 & $0.774(0.656-0.914)$ & 0.003 & $0.775(0.632-0.950)$ & 0.014 \\
\hline 4 & $0.764(0.622-0.939)$ & 0.010 & 0.768 (0.591-0.997) & 0.048 \\
\hline
\end{tabular}

Alcohol drink: 1 - person who had lifetime drinking experience, 0 - never drink; Income: quartile subgroup for gross house income.

OR: odds ratio; $\mathrm{Cl}$ : confidence interval; PSM: propensity score matching. 
Table 5. Logistic regression analysis for the occurrence of hypertension and related factors (Hg concentration $15 \mu \mathrm{g} / \mathrm{L})$

\begin{tabular}{|c|c|c|c|c|}
\hline \multirow[t]{2}{*}{ Related factors } & \multicolumn{2}{|l|}{ All subjects } & \multicolumn{2}{|l|}{ PSM subjects } \\
\hline & OR $(95 \% \mathrm{Cl})$ & $p$-value & OR $(95 \% \mathrm{Cl})$ & $p$-value \\
\hline Hg concentration (ref $\geq 15$ ) & $1.426(1.066-1.908)$ & 0.017 & $1.450(1.026-2.049)$ & 0.035 \\
\hline Sex $(r e f=$ male $)$ & 0.947 (0.831-1.079) & 0.416 & $0.980(0.673-1.428)$ & 0.918 \\
\hline Age & $1.037(1.032-1.042)$ & 0.000 & 1.037 (1.019-1.056) & 0.000 \\
\hline Smoking (ref = current) & & 0.465 & & 0.432 \\
\hline Ex & $0.984(0.814-1.190)$ & 0.942 & $1.335(0.750-2.377)$ & 0.326 \\
\hline Non & 1.062 (0.895-1.261) & 0.367 & 1.017 (0.599-1.728) & 0.949 \\
\hline Alcohol drink $(r e f=0)$ & 0.987 (0.879-1.108) & 0.959 & $1.130(0.804-1.590)$ & 0.481 \\
\hline Income $($ ref $=1)$ & & 0.002 & & 0.742 \\
\hline 2 & $1.000(0.868-1.151)$ & 0.897 & $1.254(0.810-1.942)$ & 0.311 \\
\hline 3 & $0.774(0.656-0.914)$ & 0.002 & 1.142 (0.702-1.855) & 0.593 \\
\hline 4 & $0.764(0.622-0.939)$ & 0.008 & $1.017(0.564-1.833)$ & 0.955 \\
\hline
\end{tabular}

Alcohol drink: 1 - person who had lifetime drinking experience, 0 - never drink; Income: quartile subgroup for gross house income.

OR: odds ratio; $\mathrm{Cl}$ : confidence interval; PSM: propensity score matching.

\section{DISCUSSION}

This study assessed the mercury exposure levels of residents around abandoned metal mines in Gyeonggi, Gangwon, Gyeongbuk, Gyeongnam, Jeonla and Chungcheong provinces for four years from 2008 to 2011 and compared the difference in the prevalence of hypertension according to the concentration of mercury in the local residents. To increase the reliability of the subjects' presence of hypertension, using data that blood pressure measurements, interviews, and medical history of hypertension were used.

The difference in blood mercury concentration according to the characteristics of residents showed a higher blood mercury level in male than in female. The difference in mercury concentration by age was statistically significant and showed a higher mercury concentration at the age of less than 65-year group. In the case of drinking, high mercury concentrations were found in the lifetime drinkers and statistically significant. Smoking has a high level of mercury concentration in current smokers and quit smokers and had statistically significant. In last, income level showed the highest mercury concentration in the highest income group and had statistically significant.

We compared the prevalence of hypertension among the residents by dividing the blood mercury concentration by the higher and lower than the US environmental standard value of $5.8 \mu \mathrm{g} / \mathrm{L}$ and HBM-II level $15 \mu \mathrm{g} / \mathrm{L}$. After adjustment for demographic characteristics, the prevalence of hypertension was higher in the high blood mercury concentration group and it was statistically significant. To investigate the relationship between mercury concentration and blood pressure, logistic regression analysis after adjusting for sex, age, smoking, drinking, and income also showed higher risk of hypertension in the group with higher mercury concentration than lower group.

In result of association between general characteristic and mercury concentration, there were differences in age, sex, smoking, drinking and income levels. In previous paper that reported differences in mercury concentrations according to sex, with a higher mercury concentration in males than females [9] and papers that published in opposition $[10,11]$, which showed higher results in men in this study. 
In addition, in this study, mercury levels in blood were higher in the highest income group, according to Shin et al. [12], the higher the BMI, the higher the mercury in the blood. This study also showed high results in the higher income group, suggesting that the mercury concentration has increased due to the influence of BMI and fat.

In previous papers, several results have been published regarding the relationship between exposure to mercury and hypertension. In a study of Nunavik's Inuit, it was reported that blood mercury level and blood pressure were highly correlated [13], studies in Greenland and Denmark have shown a significant correlation between blood mercury and blood \& pulse pressure [14], study in Amazon, systolic blood pressure was increased in subjects with high mercury levels of hair [15], Choi and colleagues [16] observed positive correlation between blood mercury concentration and systolic and diastolic blood pressures.

However, some studies have shown opposite results. In the same cohort study that tracked the same subjects on Faeroe Island, as reported by Sørensen et al. [17,18], seven-year-old children who had been exposed to high mercury levels during pregnancy showed high systolic blood pressure, but after 7 years, there was no effect when they were 14 years old. And in Oka et al.'s study, individuals with fetal Minamata disease had low pulse pressure when compared to the control group[2].

In this study, there was a significant correlation between blood mercury and blood pressure, and the prevalence of hypertension was high in the group with high blood mercury concentration. There are several hypotheses about the mechanism of the effect of mercury concentration on blood pressure, one is that mercury causes injury of the blood vessels and hypertension, proven through animal experiments [19] and human studies [20], Another one is mercury can induce lesions in the vascular bed, and mercury accumulation in the human body is associated with accelerated atherosclerosis. So this atherosclerosis induce hypertension [21,22]. A known mechanism of that is attributed to an enhancement of lipid peroxidation, as mercury generates reactive oxygen species, reduces the antioxidative capacity by binding to sulfhydryl groups, and counteracts the antioxidative effect of selenium [23]. And many studies have shown that mercury increases not only the risk of hypertension but the risk of coronary heart disease, myocardial infarction $[24,25]$.

Ministry of Food and Drug Safety conducted a survey of the blood mercury concentrations of 10,909 people in Korea from 2008 to 2011. They announced the average mercury concentration per capita was $3.45 \mu \mathrm{g} / \mathrm{L}$, which is $28 \%$ of the food tolerable weekly intake, so it means it's safe level [26]. On the other hand, the average mercury concentration of the residents affected by the abandoned metal mines was $5.21 \mu \mathrm{g} / \mathrm{L}$ (standard deviation: 4.53), which difference was about $1.8 \mu \mathrm{g} / \mathrm{L}$, indicating that the mercury concentration in the residents around abandoned metal mines were high, it is estimated that the longer the area is located in the area, the longer the exposure period and the long-term effect of mercury.

We estimated residents around abandoned metal mines to have chronic, direct or indirect effects of mercury on crops, soil, and drinking water around abandoned metal mines, therefore, it is thought that the occurrence of hypertension in the residents around abandoned metal mines are likely to be increased due to the influence of mercury on injury of vessels, atherosclerosis.

In addition, the majority of abandoned metal mines are into a suburban area that does not receive much health care, there is a high probability that blood pressure control in 
hypertensive patients will not be performed properly, this leads to another cardiovascular disease caused by uncontrolled hypertension.

Therefore, we should set the blood mercury concentration standard for our country and more blood pressure and health care will be needed for those who are above the threshold and those with hypertension.

The limitations of this study may be that other harmful substances other than mercury may not be considered, and the survey on dietary habits, obesity, occupation, and survey of residents during the survey are insufficient.

\section{CONCLUSIONS}

The average mercury concentration of residents affected by abandoned metal mines was high and the prevalence of hypertension was higher in residents with high mercury concentration than in residents with low mercury concentrations.

The relationship between blood mercury and hypertension has not yet been clarified, but this study showed a significant correlation between mercury and hypertension. So, local residents affected by abandoned metal mines are likely to be exposed to heavy metals such as mercury continuously, the high participation rate of the local residents of the abandoned residents' health survey is required and it is necessary to establish the blood mercury concentration standard suitable for Korea and to continuously monitor people who are higher than the standard value and the hypertensive patients.

\section{ACKNOWLEDGEMENTS}

We would like to thank the Environmental Health Center, Dong-A University for offering raw-data.

\section{REFERENCES}

1. Fitzgerald W. Is mercury increasing in the atmosphere? The need for an atmospheric mercury network (AMNET). Water Air Soil Pollut 1995;80(1-4):245-54. CROSSREF

2. Oka T, Matsukura M, Okamoto M, Harada N, Kitano T, Miike T, et al. Autonomic nervous functions in fetal type Minamata disease patients: assessment of heart rate variability. Tohoku J Exp Med 2002;198(4):215-21. PUBMED | CROSSREF

3. Houston MC. The role of mercury and cadmium heavy metals in vascular disease, hypertension, coronary heart disease, and myocardial infarction. Altern Ther Health Med 2007;13(2):S128-33. PUBMED

4. Carmignani M, Boscolo P, Artese L, Del Rosso G, Porcelli G, Felaco M, et al. Renal mechanisms in the cardiovascular effects of chronic exposure to inorganic mercury in rats. Br J Ind Med 1992;49(4):226-32. PUBMED

5. Kim MH, Sho YS, Kim EJ, Chung SY, Hong MK. Studies on heavy metal contamination of agricultural products, soils and irrigation waters in abandoned mines. J Food Hyg Saf 2002;17(4):178-82. PUBMED 
6. US Environmental Protection Agency. Technical fact sheet: trends in blood mercury concentrations among women of childbearing age. NHANES, 1999-2010. Washington, D.C.: United States Environmental Protection Agency; 2013. p. 2-12.

7. Schulz C, Angerer J, Ewers U, Kolossa-Gehring M. The German human biomonitoring commission. Int J Hyg Environ Health 2007;210(3-4):373-82. PUBMED | CROSSREF

8. The Korean Society of Hypertension. 2018 hypertension guidelines. Seoul: The Korean Society of Hypertension; 2018.

9. Monteiro LR, Lopes HD. Mercury content of swordfish, Xiphias gladius, in relation to length, weight, age, and sex. Mar Pollut Bull 1990;21(6):293-6.

PUBMED | CROSSREF

10. Batáriová A, Spevácková V, Benes B, Cejchanová M, Smíd J, Cerná M. Blood and urine levels of Pb, Cd and $\mathrm{Hg}$ in the general population of the Czech Republic and proposed reference values. Int J Hyg Environ Health 2006;209(4):359-66. PUBMED | CROSSREF

11. McRill C, Boyer LV, Flood TJ, Ortega L. Mercury toxicity due to use of a cosmetic cream. J Occup Environ Med 2000;42(1):4-7.

PUBMED | CROSSREF

12. Shin YY, Ryu IK, Park MJ, Kim SH. The association of total blood mercury levels and overweight among Korean adolescents: analysis of the Korean National Health and Nutrition Examination Survey (KNHANES) 2010-2013. Korean J Pediatr 2018;61(4):121-8. PUBMED | CROSSREF

13. Valera B, Dewailly E, Poirier P. Environmental mercury exposure and blood pressure among Nunavik Inuit adults. Hypertension 2009;54(5):981-6. PUBMED | CROSSREF

14. Pedersen EB, Jørgensen ME, Pedersen MB, Siggaard C, Sørensen TB, Mulvad G, et al. Relationship between mercury in blood and 24-h ambulatory blood pressure in Greenlanders and Danes. Am J Hypertens 2005;18(5 Pt 1):612-8. PUBMED | CROSSREF

15. Fillion M, Mergler D, Sousa Passos CJ, Larribe F, Lemire M, Guimarães JR. A preliminary study of mercury exposure and blood pressure in the Brazilian Amazon. Environ Health 2006;5:29. PUBMED | CROSSREF

16. Choi AL, Weihe P, Budtz-Jørgensen E, Jørgensen PJ, Salonen JT, Tuomainen TP, et al. Methylmercury exposure and adverse cardiovascular effects in Faroese whaling men. Environ Health Perspect 2009;117(3):367-72. PUBMED | CROSSREF

17. Grandjean P, Murata K, Budtz-Jørgensen E, Weihe P. Cardiac autonomic activity in methylmercury neurotoxicity: 14-year follow-up of a Faroese birth cohort. J Pediatr 2004;144(2):169-76. PUBMED | CROSSREF

18. Sørensen N, Murata K, Budtz-Jørgensen E, Weihe P, Grandjean P. Prenatal methylmercury exposure as a cardiovascular risk factor at seven years of age. Epidemiology 1999;10(4):370-5. PUBMED | CROSSREF

19. Wakita Y. Hypertension induced by methyl mercury in rats. Toxicol Appl Pharmacol 1987;89(1):144-7. PUBMED | CROSSREF

20. Perry HM Jr, Yunice A, Erlanger M, Schoepfle E, Perry EF. Hypertension and tissue metal levels following intravenous cadmium, mercury, and zinc. Am J Physiol 1970;219(3):755-61. PUBMED | CROSSREF

21. Salonen JT, Seppänen K, Lakka TA, Salonen R, Kaplan GA. Mercury accumulation and accelerated progression of carotid atherosclerosis: a population-based prospective 4-year follow-up study in men in eastern Finland. Atherosclerosis 2000;148(2):265-73. PUBMED | CROSSREF

22. Yoshizawa K, Rimm EB, Morris JS, Spate VL, Hsieh CC, Spiegelman D, et al. Mercury and the risk of coronary heart disease in men. N Engl J Med 2002;347(22):1755-60. PUBMED | CROSSREF

23. Salonen JT, Seppänen K, Nyyssönen K, Korpela H, Kauhanen J, Kantola M, et al. Intake of mercury from fish, lipid peroxidation, and the risk of myocardial infarction and coronary, cardiovascular, and any death in eastern Finnish men. Circulation 1995;91(3):645-55.

PUBMED | CROSSREF 
24. Guallar E, Sanz-Gallardo MI, van't Veer P, Bode P, Aro A, Gómez-Aracena J, et al. Mercury, fish oils, and the risk of myocardial infarction. N Engl J Med 2002;347(22):1747-54. PUBMED | CROSSREF

25. Halbach S. Mercury compounds: lipophilicity and toxic effects on isolated myocardial tissue. Arch Toxicol 1990;64(4):315-9.

PUBMED | CROSSREF

26. Ministry of Food and Drug Safety. Exposure level of mercury of Korean people is safe. Cheongju: Ministry of Food and Drug Safety; 2014. 